\title{
STRUCTURAL QUALITY OF SOILS CULTIVATED WITH COFFEE AND PASTURE IN AN ENVIRONMENTAL PROTECTION AREA ${ }^{(1)}$
}

\author{
Vico Mendes Pereira Lima ${ }^{(2)}$, Ciro Augusto de Souza Magalhães ${ }^{(3)}$, \\ Geraldo César de Oliveira ${ }^{(4)} \&$ José Maria de Lima ${ }^{(5)}$
}

\begin{abstract}
Studies of soils in Environmental Protection Areas (EPAs) are of great importance, because they are an essential component of ecosystems, directly interfering in environmental sustainability. The objective of this study was to evaluate the structural quality of soil cultivated with coffee and used as pasture in the Capituva's River microbasin, which is located in the Environmental Protection Area in Coqueiral, south of the state of Minas Gerais. Uniaxial compression test (preconsolidation test) and soil resistance to penetration were used. Undisturbed samples were taken from the surface layer $(0-5 \mathrm{~cm})$ of the soils in the area: a typic dystrophic Red Latosol (LVd - Oxisol), a typic eutrophic Red Argisol (PVe - Ultisol), and a typic dystrophic Haplic Cambisol (CXbd - Inceptisol). A significant linear positive correlation was observed between the results of the preconsolidation test and soil resistance to penetration. Load bearing capacity of soil could be estimated accordingly by means of penetration resistance for LVd, PVe, and CXbd. Cambisol - CXbd showed lower loading support capacity and resistance to penetration than LVd and PVe, due to the better crop management in this soil that resulted in higher physical quality which accounts for higher production and environmental sustainability.
\end{abstract}

Index terms: compression, environmental sustainability, soil water availability, load support capacity, soil penetration resistance.

\footnotetext{
(1) Part of the first author's dissertation submitted to the Graduate Program in Soil Science, Federal University of Lavras - UFLA. Received for publication in August 2009 and approved in June 2010.

(2) Doctoral Student, Department of Soil Science, UFLA, C.P. 3037, CEP 37200-000, Lavras (MG). Scholarship granted by FAPEMIG. E-mail: vicomendes@hotmail.com

(3) Doctoral Student, Department of Soil Science, UFLA, C.P. 3037, CEP 37200-000, Lavras (MG). Scholarship granted by CAPES. E-mail:ciroasm@yahoo.com.br

(4) Associate Professor, Department of Soil Science, UFLA, C.P. 3037, CEP 37200-000, Lavras (MG). E-mail: geraldooliveira@dcs.ufla.br

(5) Associate Professor, Department of Soil Science, UFLA, C.P. 3037, CEP 37200-000, Lavras (MG). E-mail: jmlima@dcs.ufla.br
} 


\title{
RESUMO: QUALIDADE ESTRUTURAL DE SOLOS CULTIVADOS COM CAFÉ E PASTAGEM EM ÁREA DE PROTEÇÃO AMBIENTAL
}

\begin{abstract}
O estudo do solo em áreas de proteção ambiental (APAs) é de grande importância, pelo fato deste ser componente essencial dos ecossistemas, interferindo diretamente na sustentabilidade do ambiente. Objetivou-se, com este trabalho, avaliar a qualidade estrutural de solos cultivados com café e pastagem na microbacia do Ribeirão Capituvas, inserido na APA Coqueiral, tendo por base uma caracterização pedológica e utilizando-se os ensaios de compressão uniaxial e resistência do solo à penetração. Coletaram-se amostras indeformadas na camada superficial $(0-5 \mathrm{~cm})$ do Latossolo Vermelho distrófico típico (LVd), do Argissolo Vermelho eutrófico típico (PVe) e do Cambissolo Háplico distrófico típico (CXbd). Verificou-se correlação positiva, linear e significativa entre a pressão de preconsolidação e a resistência do solo à penetração, podendo a capacidade de suporte de carga ser adequadamente estimada, por meio da resistência à penetração, para LVd, PVe e CXbd. Para os usos estudados, o CXbd apresentou a menor capacidade de suporte de carga e a menor resistência à penetração, comparado ao LVd e ao PVe, devido ao bom manejo do solo resultando em alta qualidade física e no cumprimento da função produtiva e da sustentabilidade ambiental desse solo.
\end{abstract}

Termos de indexação: compactação, sustentabilidade ambiental, disponibilidade hídrica do solo, capacidade de suporte de carga, resistência do solo à penetração.

\section{INTRODUCTION}

Environmental Protection Areas are recognized for linking the conservation of natural resources with sustainable crop production. Improving human activities in these conservation units based on crop production potential and soil limitation studies, showed significant results on maintaining diversity of species and natural processes in these environments.

As an essential component of ecosystems, soils directly influence sustainability of these areas. Thus, understanding the processes in the soil-plant aimed at the management of soil quality must be preceded by a search for soil quality (Vezzani \& Mielniczuk, 2009). Every producer is very important in the maintenance of sustainability, since their decisions about soil management affects the entire hydrographic basin in which their land is located.

Innumerous authors point out the importance of studying soil physical qualities (Oliveira et al., 2003; Tormena et al, 2007; Severiano et al., 2008; Ajayi et al., 2009). Attributes that define the physical quality express environmental stability, mainly when it is evaluated using physical characteristics and properties that directly correlate with soil role within hydric aspects.

In this context, evaluations of the load bearing capacity of soil (Dias Junior et al., 2002) in order to predict compression, based on uniaxial compression tests (Dias Junior \& Pierce, 1995; Peng et al., 2004; Gontijo et al., 2007) and soil penetration resistance studies (Tormena et al., 1998; Oliveira et al., 2007; Severiano et al., 2008, Ajayi et al., 2009) have been widely used since they consider several soil attributes in a single evaluation.
Some soil physical attributes can support inferences on soil quality, since differences in these attributes can help to define specific soil management practices in order to improve the edaphic environment for plant growth.

The objective of this research was to evaluate the structural quality comparing uniaxial compression and soil penetration resistance tests in soils cultivated with coffee and used as pasture in the Capituva's River microbasin, which is part of the Coqueiral Environmental Protection Area.

\section{MATERIALS AND METHODS}

The research was carried out in the Capituva's River microbasin located in the Coqueiral Environmental Protection Area, in the south of the state of Minas Gerais, Brazil. According to Koppen, the local climate is classified as Cwa: rainy and mild summer with a moderate temperature $\left(21^{\circ} \mathrm{C}\right.$ annual average). The average annual rainfall is $1,500 \mathrm{~mm}$ and air relative humidity is $70 \%$ (Emater, 2002).

This microbasin was selected because it is representative of the Coqueiral Environmental Protection Area, which represents quite well the southern region of the state of Minas Gerais, as related to land use, terrain, and soil classes. Soils were classified using the Brazilian Soil Classification System (Embrapa, 2006) up to the fourth categorical level, using the Soil Description and Field Sampling Manual (Santos et al., 2005) to describe the morphology of the three complete soil profiles and nineteen complementary soil profiles. 
The soils are mostly shallow, formed from weathering of granitic rocks from the pre-Cambrian period (Brasil, 1962). The landscape has been dissected by water erosion and is mainly undulated, whose surfaces vary from convex to concave, at the top of hills and the bottom of valleys, respectively.

This microbasin has an area of $33.8 \mathrm{ha}$, with typic dystrophic Haplic Cambisol (CXbd - Inceptisol), $51 \%$ of the area, typic eutrophic Red Argisol (PVe - Ultisol), $33 \%$ of the area, and a typic dystrophic Red Latosol (LVd - Oxisol), $8 \%$ of the area. In addition to these soils, a Litholic Neosol, associated with rocky outcroppings, and mixed footslope and toeslope soils are also found along the drainage network, which takes up $8 \%$ of the area. The chemical properties of these soils are shown on table 1 and the physical and mineralogical characterization on table 2 .
Coffee and pasture (Brachiaria decumbens), respectively, make up 8 and $84 \%$ of the area. The soils were tilled for coffee and pasture implementation and have been cultivated for about eight years; they were previously used as natural grazing. Although the LVd area has some old terraces, the farmers have used this area for pasture only with no other soil conservation practices. In the PVe area, the farmer hasn't adopted adequate soil conservation and management practices; for this reason the coffee crop is in bad shape and the pastures are degraded. On the other hand, in the CXbd area, there are terraces and adequate practices for coffee cropping; the farmer takes good care of native areas, keeping the soil surface covered between rows of the crop and an appropriate management in the pasture area. All farmers use manual harvesting for coffee crops.

Table 1. pH in water, soil organic matter (SOM) and sorptive complex components of the soils in the Capituva's River microbasin, Coqueiral Environmental Protection Area

\begin{tabular}{|c|c|c|c|c|c|c|c|c|c|}
\hline Layer $^{(1)}$ & $\mathbf{p H}$ & SOM & $\mathbf{P}$ & $\mathbf{K}$ & $\mathbf{C a}^{2+}$ & $\mathbf{M g}^{2+}$ & $\mathrm{Al}^{3+}$ & $\mathbf{V}^{(2)}$ & $\mathbf{m}^{(3)}$ \\
\hline $\mathrm{cm}$ & & dag kg $\cdot 1$ & \multicolumn{2}{|c|}{$\mathrm{mg} \mathrm{dm}^{-3} \_$} & \multicolumn{3}{|c|}{$\mathrm{cmol}_{\mathrm{c}} \mathrm{dm}^{-3}$} & \multicolumn{2}{|c|}{ 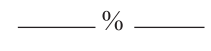 } \\
\hline \multicolumn{10}{|c|}{ Typic dystrophic Red Latosol - LVd } \\
\hline $\begin{array}{c}0-5 \\
80-100\end{array}$ & $\begin{array}{l}4.5 \\
4.5\end{array}$ & $\begin{array}{l}3.1 \\
1.8\end{array}$ & $\begin{array}{l}1.4 \\
0.6\end{array}$ & $\begin{array}{r}41 \\
8\end{array}$ & $\begin{array}{l}0.2 \\
0.5\end{array}$ & $\begin{array}{l}0.1 \\
0.2\end{array}$ & $\begin{array}{l}2.0 \\
1.5\end{array}$ & $\begin{array}{l}3.1 \\
6.8\end{array}$ & $\begin{array}{l}83 \\
68\end{array}$ \\
\hline \multicolumn{10}{|c|}{ Typic eutrophic Red Argisol - PVe } \\
\hline $0-5$ & 5.7 & 2.2 & 1.2 & 89 & 2.3 & 0.9 & 0.2 & 46.2 & 6 \\
\hline $50-70$ & 5.8 & 0.6 & 1.2 & 33 & 1.8 & 0.8 & 0.2 & 50.8 & 7 \\
\hline \multicolumn{10}{|c|}{ Typic dystrophic Haplic Cambisol - CXbd } \\
\hline $0-5$ & 6.0 & 2.1 & 2.8 & 246 & 2.1 & 1.1 & 0.2 & 54.5 & 5 \\
\hline $25-45$ & 5.4 & 0.8 & 0.9 & 131 & 0.2 & 0.1 & 1.2 & 15.1 & 65 \\
\hline
\end{tabular}

(1) Depth corresponding to the surface layer and B (diagnostic) soil horizon. ${ }^{(2)}$ Base saturation (V). ${ }^{(3)}$ Saturation by Al (m). Analyses carried out using the Embrapa (1997) methodology.

Table 2. Physical and mineralogical characterization of soils in the Capituva's River microbasin, Coqueiral EPA

\begin{tabular}{|c|c|c|c|c|c|c|c|c|c|}
\hline \multirow{2}{*}{ Horizon } & \multirow{2}{*}{$\mathbf{D p}{ }^{(1)}$} & \multicolumn{3}{|c|}{ Grain size } & \multicolumn{3}{|c|}{ Sulfuric attack } & \multirow{2}{*}{$\mathbf{K i}$} & \multirow{2}{*}{$\mathbf{K r}$} \\
\hline & & Clay & Silt & Sand & $\overline{\mathrm{SiO}_{2}}$ & $\mathrm{Al}_{2} \mathrm{O}_{3}$ & $\overline{\mathrm{Fe}_{2} \mathrm{O}_{3}}$ & & \\
\hline & $\mathrm{Mg} \mathrm{m}^{-3}$ & \multicolumn{6}{|c|}{$\mathrm{g} \mathrm{kg}^{-1}$} & & \\
\hline \multicolumn{10}{|c|}{ Typic dystrophic Red Latosol - LVd } \\
\hline A & 2.50 & 552 & 115 & 333 & & . & - & - & 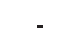 \\
\hline $\mathrm{Bw}$ & 2.67 & 589 & 91 & 320 & 188 & 208 & 89 & 1.53 & 1.20 \\
\hline \multicolumn{10}{|c|}{ Typic eutrophic Red Argisol - PVe } \\
\hline A & 2.53 & 264 & 184 & 552 & & - & 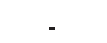 & - & - \\
\hline $\mathrm{Bt}$ & 2.70 & 560 & 127 & 313 & 231 & 208 & 101 & 1.89 & 1.44 \\
\hline \multicolumn{10}{|c|}{ Typic dystrophic Haplic Cambisol - CXbd } \\
\hline A & 2.60 & 270 & 200 & 530 & - & - & - & - & - \\
\hline $\mathrm{Bi}$ & 2.60 & 213 & 271 & 516 & 166 & 147 & 25 & 1.92 & 1.73 \\
\hline
\end{tabular}

(1) Particle density by the volumetric balloon method. Ki: molecular ratio $\mathrm{SiO}_{2} / \mathrm{Al}_{2} \mathrm{O}_{3} ; \mathrm{Kr}$ : molecular ratio $\mathrm{SiO}_{2} /\left(\mathrm{Al}_{2} \mathrm{O}_{3}+\mathrm{Fe}_{2} \mathrm{O}_{3}\right)$. Analyses carried out using the Embrapa (1997) methodology. 
Undisturbed soils were sampled in triplicate in volumetric rings $(8.25 \mathrm{~cm}$ high by $6.95 \mathrm{~cm}$ diameter) for saturated-soil hydraulic conductivity $\left(\mathrm{K}_{\mathrm{sat}}\right)(\mathrm{Lima}$ et al., 1990), soil density (Ds) (Blake \& Hartge, 1986) and penetration resistance at $10 \mathrm{kPa}$ tension $\left(\mathrm{RP}_{10 \mathrm{kPa}}\right)$, as in Tormena et al. (1998) adapted for penetration speed; obtaining a total of 54 samples (3 soils x 2 uses x 3 points x 3 repetitions).

For the uniaxial compression and soil penetration resistance tests, undisturbed samples were collected using an Uhland sampler in the superficial layer of each soil in $6.40 \mathrm{~cm}$ diameter and $2.50 \mathrm{~cm}$ high volumetric rings, with six replicates at each sampling site, obtaining a total of 108 samples (3 soils x 2 uses $\mathrm{x} 3$ points $\mathrm{x} 6$ repetitions).

Undisturbed samples were saturated from the bottom of each column with water using a suction column (Reinert \& Reichert, 2006). Then, these samples were air dried until water content was between -10 and $-1,500 \mathrm{kPa}$; half of them (54) were submitted to uniaxial compression tests (Dias Junior, 1994) and the other half to penetration resistance tests (RP) (Tormena et al., 1998) adapted for penetration speed.

The uniaxial compression test was at the following pressures: 25, 50, 100, 200, 400, 800, and $1,600 \mathrm{kPa}$; each level of pressure was applied until $90 \%$ of maximum deformation was reached (Taylor, 1948), before the next level. Then, the samples were dried at $105{ }^{\circ} \mathrm{C}$ for $48 \mathrm{~h}$ in order to determine soil density (DS). Preconsolidation pressure $\left(\sigma_{\mathrm{p}}\right)$ was estimated as in Dias Junior \& Pierce (1995). Load bearing capacity models (CSC) were obtained by adjusting $\sigma_{\mathrm{p}}$ as a function of volumetric water content of the soil sample (Gontijo et al., 2007), using equation 1 (Dias Junior, 1994). Comparisons of regression equations were done as in Snedecor \& Cochran (1989).

$$
\sigma_{\mathrm{p}}=10^{(\mathrm{a}+\mathrm{b} \theta)}
$$

where $\sigma_{\mathrm{p}}$ : preconsolidation pressure $(\mathrm{kPa})$; $\mathrm{a}$ and $\mathrm{b}$ : fitting parameters; and $\theta$ : volumetric water content $\left(\mathrm{m}^{3} \mathrm{~m}^{-3}\right)$.

RP was determined using a Marconi MA 933 Model electronic penetration-meter, at constant speed $\left(10 \mathrm{~cm} \mathrm{~min}{ }^{-1}\right)$, after equilibrating the sample for the desired water content; four tests were done in each sample. Then, the samples were oven dried at $105^{\circ} \mathrm{C}$ for $48 \mathrm{~h}$ to determine Ds. The RP values $\left(\mathrm{kgf} \mathrm{cm}^{-2}\right)$ were multiplied by a factor of 0.098 to transform them into $\mathrm{MPa}$ and adjusted to nonlinear models as a function of volumetric water content $(\theta)$, using equation 2 (Dias Junior, 1994). Comparisons of the regression equations were carried out as in Snedecor \& Cochran (1989).

$$
\mathrm{RP}=10^{(\mathrm{a}+\mathrm{b} \theta)}
$$

where $\mathrm{RP}=$ penetration resistance $(\mathrm{MPa})$; $\mathrm{a}$ and $\mathrm{b}=$ fitting parameters; and $\theta=$ volumetric water content $\left(\mathrm{m}^{3} \mathrm{~m}^{-3}\right)$.
Data exploration analysis was done to the $\mathrm{Ds}, \mathrm{K}_{\mathrm{sat}}$ and $\mathrm{RP}_{10 \mathrm{kPa}}$ results in order to obtain distribution and dispersion measures. Analysis of normality of error was done using the Shapiro-Wilk test. Analysis of variance and means comparison by the Scott-Knott test to $5 \%$ were done using the Sisvar statistical program (Ferreira, 2005).

\section{RESULTS AND DISCUSSION}

For the three soil classes, the higher the Ds values, the higher the $\mathrm{RP}_{10 \mathrm{kPa}}$ and lower the $\mathrm{K}_{\text {sat }}$ values (Table 3). The soil under the pasture had higher Ds which is accounted for by the constant pressure that is applied by grazing cattle; as a consequence, high $\mathrm{RP}$ and low $\mathrm{K}_{\mathrm{sat}}$ values are found in this pasture area.

A positive and significant correlation between Ds and $\mathrm{K}_{\mathrm{sat}}(0.71)$ was found, despite the high variation coefficient in $\mathrm{K}_{\text {sat }}$ data $(\mathrm{CV}=86 \%)$. These results are justified by the fact that $\mathrm{K}_{\text {sat }}$ is a function of pore distribution by size, directly varying with the amount of macropores (Ferreira \& Dias Junior, 2001). Macropores are thus related to Ds, in a way that their decrease means increased density.

According to the Soil Survey Staff (1993), $\mathrm{K}_{\mathrm{sat}}$ can be classified into fast, > 254; moderate to fast, 254127; moderate, 127-63.5; slow to moderate, 63.5-20; slow, 20-5; and very slow, $<5 \mathrm{~mm} \mathrm{~h}^{-1}$. In general, the cultivated soils in this microbasin area had moderate to slow $\mathrm{K}_{\text {sat }}$. The best scenario for water infiltration in soil is found in the CXdb soil, which shows a moderate $\mathrm{K}_{\text {sat }}$.

Table 3. Soil density (Ds), hydraulic conductivity of saturated soil $\left(\mathrm{K}_{\mathrm{sat}}\right)$, and penetration resistance at $10 \mathrm{kPa}$ tension $\left(\mathrm{RP}_{10 \mathrm{kPa}}\right)$ of the soil surface layer cultivated with coffee and pasture in the

\begin{tabular}{|c|c|c|c|}
\hline Land use & Ds & $\mathbf{K}_{\text {sat }}$ & $\mathbf{R P}_{10 \mathrm{kPa}}$ \\
\hline & $\mathrm{Mg} \mathrm{m}^{-3}$ & $\mathrm{~mm} \mathrm{~h}^{-1}$ & $\mathrm{MPa}$ \\
\hline $\begin{array}{l}\text { Coffee } \\
\text { Pasture }\end{array}$ & $\begin{array}{l}\mathrm{Ty} \\
1.37 \mathrm{a} \\
1.50 \mathrm{~b}\end{array}$ & $\begin{array}{r}\text { phic Red } \\
117.97 \mathrm{a} \\
23.06 \mathrm{~b}\end{array}$ & $\begin{array}{r}-\mathrm{LVd} \\
2.06 \mathrm{a} \\
3.03 \mathrm{~b}\end{array}$ \\
\hline $\begin{array}{l}\text { Coffee } \\
\text { Pasture }\end{array}$ & $\begin{array}{l}1.44 \mathrm{a}^{\mathrm{T}} \\
1.44 \mathrm{a}^{2}\end{array}$ & $\begin{array}{r}\text { phic Red } \\
31.33 \mathrm{a} \\
15.86 \mathrm{a}\end{array}$ & $\begin{array}{r}-\mathrm{PVe} \\
1.84 \mathrm{a} \\
2.54 \mathrm{~b}\end{array}$ \\
\hline $\begin{array}{l}\text { Coffee } \\
\text { Pasture }\end{array}$ & $\begin{array}{l}\text { Typic } \\
1.32 \mathrm{a} \\
1.46 \mathrm{~b}\end{array}$ & $\begin{array}{r}\text { Haplic } \\
120.18 \mathrm{a} \\
27.52 \mathrm{~b}\end{array}$ & $\begin{array}{c}-\mathrm{CXbd} \\
2.27 \mathrm{a} \\
2.70 \mathrm{a}\end{array}$ \\
\hline
\end{tabular}
Capituva's River microbasin, Coqueiral EPA

Means followed by the same letter, comparing land uses within each soil in columns do not differ from each other at $5 \%$, by the Scott-Knott test. 
As can be observed, $\sigma_{p}$ (left) and RP (right), as a function of water content for LVd, PVe, and CXbd, do not point out differences on structural quality diagnosis, independent of usage as coffee plantation or pasture (Figure 1). Using the statistical procedures suggested by Snedecor \& Cochran (1989), significant difference was only found in RP of LVd. For CXbd and PVe, there were no differences between compression behavior and RP, when these soils were used either for coffee plantations or pasture.

For both coffee and pasture uses, the CSC curves get close to each other, as the water content of samples increases (Figure 1-left); at this point, water content is the main property that accounts for soil compression (Kondo \& Dias Junior, 1999). When the soil is dry, the structure is mainly responsible for soil CSC (Dias Junior, 1994). At low water content, there is a tendency for these curves to be separated from each other, due to different $\sigma_{\mathrm{p}}$ values that are always higher for soil used for coffee cultivation. This behavior is attributed to the better soil structure and resilience of soils cultivated with coffee, mainly due to greater additions of organic residues and lack of deep soil tilling (Soane, 1990).
Since no significant differences were found between CSC models in coffee and pasture areas, a single model with 18 samples was plotted. This model represents the compression behavior of the soil for both uses. Analyzing the compressive behavior of the three soils when the models were linearized $\left(\log \sigma_{\mathrm{p}}=\mathrm{a}+\mathrm{b} \theta\right)$, a higher CSC was observed in PVe, followed by LVd, and $\mathrm{CXbd}$. The three soils behave differently in terms of CSC; the curves are homogenous for regressions, not significant for the linear coefficient and significant for the angular coefficient $(\mathrm{F}=13.97, \mathrm{p}<0.001$ between CXbd and LVd; F = 6.34, p < 0.05 between $\mathrm{LVd}$ and PVe; and $\mathrm{F}=45.66, \mathrm{p}<0.001$ between CXbd and PVe) (Figure 2).

The greatest CSC observed for PVe is due to the combination of greater Ds values (Table 3) resulting from medium texture of the upper layer (Dias Junior et al., 2002) along with the more intensive use of this soil without conservation practices, as suggested by the degradation of the pasture and the coffee field. This soil had a moderate to strong structure, medium to large blocks, that, according to Peng et al. (2004), accounts for a greater load bearing capacity. Cohesion and friction forces between particles are more intense
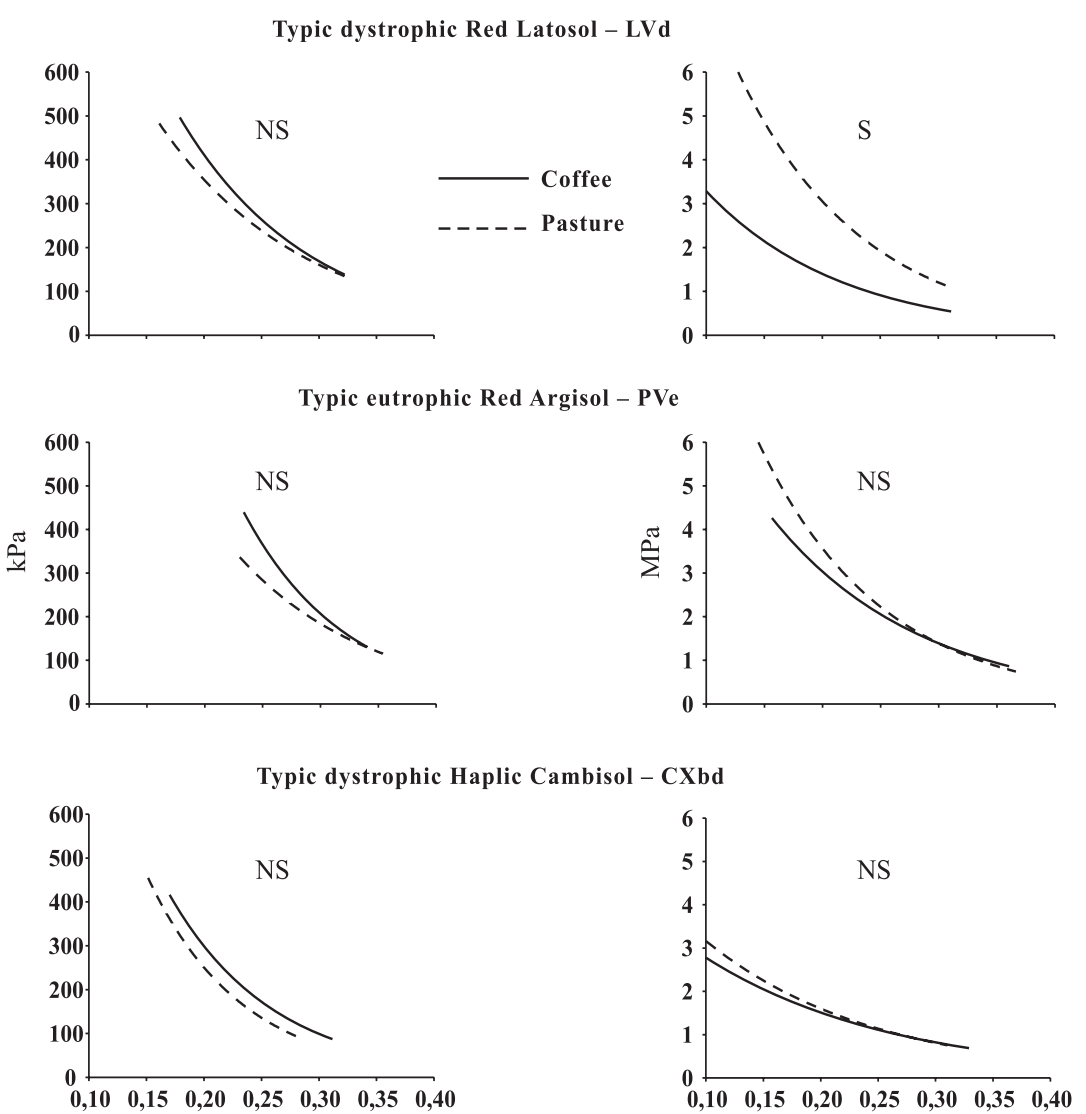

WATER CONTENT, $\mathrm{m}^{3} \mathrm{~m}^{-3}$

Figure 1. Preconsolidation pressure (left) and penetration resistance (right) in function of water content for the surface layer of soil cultivated with coffee and pasture in the Capituvas River microbasin, Coqueiral EPA. S: Models presented are significantly different; NS: models are not significantly different by the test suggested by Snedecor \& Cochran (1989). 


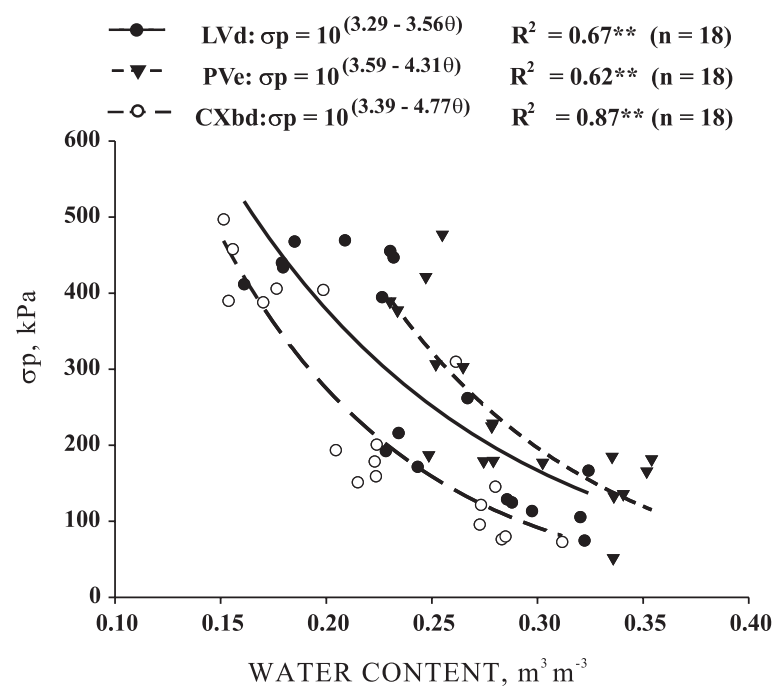

Figure 2. Load bearing capacity models in a Typic dystrophic Red Latosol (LVd), a Typic eutrophic Red Argisol (PVe), and a Typic dystrophic Haplic Cambisol (CXbd) cultivated with coffee and pasture at a depth of $0-5 \mathrm{~cm}$ in the Capituva's River microbasin, Coqueiral EPA.

in soils that have already undergone greater changes of its structure (Michel, 1976) which overcomes the effect that water would have on soil compression behavior (Kondo \& Dias Junior, 1999) in the water tension range used in this study. The pre-compression effect was also verified by Silva et al. (2002); the authors found a significant increase in preconsolidation pressure from 68 to $164 \mathrm{kPa}$ for $\mathrm{Ds}$ values of 1.3 and $1.6 \mathrm{Mg} \mathrm{m}^{-3}$, respectively, in RedYellow Argisol.

The CXbd had the lowest CSC (Figure 2). Since it is a less weathered soil $(\mathrm{Ki}=1.92)($ Table 2$)$, consequently with weak and more cohesive structure, a greater CSC was expected, compared to the other studied soils. However, this soil has a history of less degrading tension, confirmed by the better shape of pasture and the coffee plantation. It is suggested that this result is related to the owner's concern and use of adequate soil management for this area.

On the other hand, lower CSC was expected for the LVd, due to its higher weathering $(\mathrm{Ki}=1.52)$ (Table 2) that is associated with better structure, formed by small and stable aggregates, high porous space (Peng et al., 2004; Santos et al., 2005), as well as clay content. However, the LVd had an intermediate load bearing capacity, which was attributed to the degrading management that caused laminar erosion in the area. Severiano (2010) stated that Latosols with clayey- and very-clayey textures are more susceptible to compression, which can take place even when the soil is dry.

Changes in the structure of all three soils take place due to plowing and management adopted for coffee cultivation and pastures. The PVe had the highest RP values, followed by LVd and CXbd (Figure 3). RP, as a function of moisture content, was studied by several authors, such as Imhoff et al. (2000), Dias Junior et al. (2004), Oliveira et al. (2007), and Severiano et al. (2008), showing the importance of RP in determining the soil physical quality.

Significant differences were found between RP models linearized $\left(\log \sigma_{p}=a+b \theta\right)$ as a function of soil moisture content. The CXbd, differed from LVd ( $\mathrm{F}=$ $10.05 ; \mathrm{p}<0.001)$ and the LVd differed from PVe $(\mathrm{F}=$ 40.28; $p$ < 0.001) for the angular coefficient; The CXbd differed from PVe for homogeneity $(\mathrm{F}=1.88 ; \mathrm{p}<0.001)$ and angular coefficient $(\mathrm{F}=134.16 ; \mathrm{p}<0.001)$. Lower $\mathrm{RP}$ values with increasing moisture content are due to decreasing cohesion and internal friction angle (Camp \& Gill, 1969).

The amplitude of RP values is smaller for CXbd; values greater than $2.5 \mathrm{MPa}$ only were possible for moisture content smaller than $0.13 \mathrm{~m}^{3} \mathrm{~m}^{-3}$. Such RP values are restrictive for most crops (Camargo \& Alleoni, 1997). This indicates a better state of soil structural preservation (Oliveira et al., 2007), keeping in mind that these conditions are only reached when the moisture content of this soil is very low.

Higher RP values in PVe, followed by LVd and $\mathrm{CXbd}$, are in agreement with CSC results, suggesting that what changes $\sigma_{p}$ also changes RP. Some authors, such as Culley \& Larson (1987) and Lima et al. (2006), also verified significant, positive linear correlations between $R P$ and $\sigma_{p}$, showing that high $\sigma_{p}$ values are associated to RP increases. Therefore, $\sigma_{p}$ can be estimated by using RP values; this is very positive,

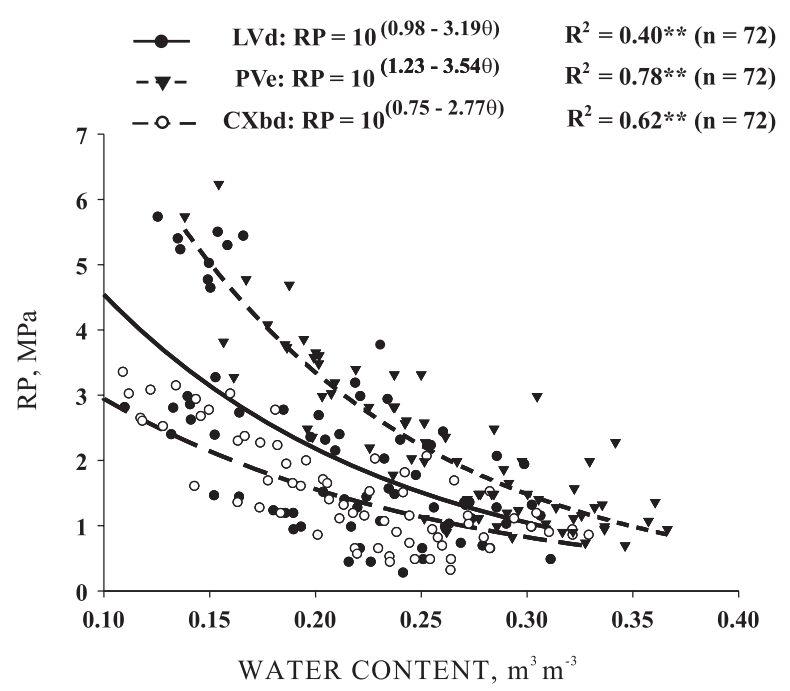

Figure 3. Penetration resistance models of a Typic dystrophic Red Latosol (LVd), a Typic eutrophic Red Argisol (PVe), and a Typic dystrophic Haplic Cambisol (CXbd) cultivated with coffee and pasture at the top layer $(0-5 \mathrm{~cm})$ in Capituva's River microbasin, Coqueiral EPA. 
since RP analyses are cheaper, simpler, and less time consuming.

Preconsolidation pressure values $\left(\sigma_{\mathrm{p}}\right)$ (soil CSC estimate) correlates significantly and positively with penetration resistance values (RP) in different volumetric water contents in soils $(\theta)$. The ratio between estimated $\sigma_{\mathrm{p}}$ values (measured in $\mathrm{kPa}$ ) and $\mathrm{RP}$ (measured in $\mathrm{MPa}$ ) for the soils in this study followed the models below, for water content between 0.1 and $0.4 \mathrm{~m}^{3} \mathrm{~m}^{-3}$.

$$
\begin{array}{ll}
\text { LVd: } & \sigma_{p}=179 R P ; R^{2}=0.99 \\
\text { PVe: } & \sigma_{p}=177 R P ; R^{2}=0.98 \\
\text { CXbd: } & \sigma_{p}=216 R P ; R^{2}=0.87
\end{array}
$$

The observed ratios were 5.6:1; 5.7:1; and 4.6:1 for LVd, PVe, and CXbd, respectively. Despite the differences between the soils, no difference was verified for this ratio, regarding $\sigma_{\mathrm{p}}$; preconsolidation pressure was $20 \%$ of RP. Canarache et al. (2000) and Mosaddeghi et al. (2003) found a ratio of 10:1 for soils from temperate climates.

A comparative evaluation of $\sigma_{p}$ and RP in plots cultivated with coffee or used as pasture within soil classes reflects the type of management to which the soil and the crop have undergone. When soils have the same mineralogy and texture, for instance, the soil under the best management (Oliveira et al., 2003), including the land use history (Kondo \& Dias Junior, 1999), will also have the best structural quality.

\section{CONCLUSIONS}

1. CSC could be accurately estimated by using RP values for $\mathrm{LVd}$, $\mathrm{PVe}$, and CXbd cultivated with coffee and pasture in the Capituva's River microbasin in the Coqueiral EPA.

2. For the land uses in this study, the CXbd had the lowest CSC and RP values, due to its better management, which results in high physical quality that accounts for higher productivity and environmental sustainability.

\section{LITERATURE CITED}

AJAYI, A.E.; DIAS JUNIOR, M.S.; CURI, N.; ARAUJO JUNIOR, C.F.; ALADENOLA, O.O.; SOUZA, T.T.T. \& INDA JUNIOR, A.V. Comparison of estimation methods of soil strength in five soils. R. Bras. Ci. Solo, 33:487-495, 2009 .

BLAKE, G.R. \& HARTGE, K.H. Bulk density. In: KLUTE, A., ed. Methods of soil analysis: Physical and mineralogical methods. 2.ed. Madison, America Society of Agronomy, Soil Science Society of America, 1986. p.363-375.
BRASIL. Ministério da agricultura. Centro Nacional de Ensino e Pesquisas Agronômicas. Levantamento de reconhecimento dos solos da região sob influência do reservatório de Furnas. Rio de Janeiro, 1962. 462p. (Boletim do Serviço Nacional de Pesquisas Agronômicas. Contribuição à Carta de Solos)

CAMARGO, O.A. \& ALLEONI, L.R.F. Compactação do solo e o desenvolvimento de plantas. Piracicaba, Escola Superior "Luiz de Queiroz", 1997. 132p.

CAMP, C.R. \& GILL, W.R. The effect of drying on soil strength parameters. Soil Sci. Soc. Am. Proc., 33:641-644, 1969.

CANARACHE, A.; HORN, R. \& COLIBAS, I. Compressibility of soils in a long term field experiment with intensive deep ripping in Romania. Soil Till. Res., 56:185-196, 2000.

CULLEY, J.L.B. \& LARSON, W.E. Susceptibility to compression of a clay loam Haplaquoll. Soil Sci. Soc. Am. J., 51:562-567, 1987.

DIAS JUNIOR, M.S.; GOMES, A.N.; ANDRADE, S.C. \& AZEVEDO, M.R. Avaliação da sustentabilidade da estrutura de Argissolos em sistemas florestais. Cerne, 8:103-114, 2002.

DIAS JUNIOR, M.S.; SILVA, A.R.; FONSECA, S. \& LEITE, F.P. Método alternativo de avaliação da pressão de preconsolidação por meio de um penetrômetro. R. Bras. Ci. Solo, 28:805-810, 2004.

DIAS JUNIOR, M.S. \& PIERCE, F.J. A simple procedure for estimating preconsolidation pressure from soil compression curves. Soil Technol., 8:139-151, 1995.

DIAS JUNIOR, M.S. Compression of three soils under longterm tillage and wheel traffic. East Lansing, Michigan State University, 1994. 114p. (Doctoral Thesis)

EMATER MG. Área de Proteção Ambiental do Município de Coqueiral. Belo Horizonte, Unidade de Consultoria e Projetos - EMATER MG, 2002. Não Paginado.

EMPRESA BRASILEIRA DE PESQUISA AGROPECUÁRIA EMBRAPA. Centro Nacional de Pesquisas de Solos. Sistema brasileiro de classificação de solos. 2.ed. Rio de Janeiro, Embrapa Solos/Brasília, Sistema de Produção de Informação, 2006. 306p.

EMPRESA BRASILEIRA DE PESQUISA AGROPECUÁRIA EMBRAPA. Manual de métodos de análise de solo. Rio de Janeiro, Serviço Nacional de Levantamento e Conservação de Solos, 1997. 247p.

FERREIRA, D.F. Estatística básica. Lavras, Universidade Federal de Lavras, 2005. 654p.

FERREIRA, M.M. \& DIAS JÚNIOR, M.S. Física do solo. Lavras, UFLA/FAEPE, 2001. 117p.

GONTIJO, I.; DIAS JUNIOR, M.S.; OLIVEIRA, M.S.; ARAUJO JÚNIOR, C.F.; PIRES, B.S. \& OLIVEIRA, C.A. Planejamento amostral da pressão de preconsolidação de um Latossolo Vermelho distroférrico. R. Bras. Ci. Solo, 31:1245-1254, 2007.

IMHOFF, S.D.C.; SILVA, A.P. \& TORMENA, C.A. Aplicações da curva de resistência no controle da qualidade física de um solo sob pastagem. Pesq. Agropec. Bras., 35:1493$1500,2000$. 
KONDO, M.K. \& DIAS JUNIOR, M.S. Compressibilidade de três Latossolos em função da umidade e uso. R. Bras. Ci. Solo, 23:211-218, 1999.

LIMA, C.L.R.; SILVA, A.P.; IMHOFF, S.D.C. \& LEÃO, T.P. Estimativa da capacidade de suporte de carga do solo a partir da avaliação da resistência à penetração. R. Bras. Ci. Solo, 30:217-223, 2006.

LIMA, J.M.; CURI, N.; RESENDE, M. \& SANTANA, D.P Dispersão do material de solo em água para avaliação indireta da erodibilidade de Latossolos. R. Bras. Ci. Solo, 14:85-90, 1990 .

MICHEL, J.K. Fundamentals of soil behavior. New York, John Wiley, 1976. 422p.

MOSADDEGHI, M.R.; HEMMAT, A.; HAJABBASI, M.A. \& ALEXANDROU, A. Pre-compression stress and its relation with the physical and mechanical properties of a structurally unstable soil in Central Iran. Soil Till. Res., 70:53-64, 2003.

OLIVEIRA, G.C.; DIAS JUNIOR, M.S.; RESCK, D.V.S. \& CURI, $\mathrm{N}$. Alterações estruturais e comportamento compressivo de um Latossolo Vermelho do Cerrado sob diferentes sistemas de manejo por 20 anos. Pesq. Agropec. Bras., 38:291-299, 2003.

OLIVEIRA, G.C.; SEVERIANO, E.C. \& MELLO, C.R. Dinâmica da resistência à penetração de um Latossolo Vermelho da Microrregião de Goiânia, GO. R. Bras. Eng. Agríc. Amb., 11:265-270, 2007.

PENG, S.H.; HORN, R.; ZHANG, B. \& ZAHO, Q.G. Mechanisms of soil vulnerability to compaction of homogenized and recompacted Ultisols. Soil Till. Res., 76:125-137, 2004.

REINERT, D.J. \& REICHERT, J.M. Coluna de areia para medir a retenção de água no solo - protótipos e teste. Ci. Rural, 36:1931-1935, 2006.

SANTOS, R.D.; LEMOS, R.C.; SANTOS, H.G.; KER, J.C. \& ANJOS, L.H.C. Manual de descrição e coleta de solo no campo. 5.ed. Viçosa, MG, Sociedade Brasileira de Ciência do Solo, 2005. 92p.
SEVERIANO, E.C. Alterações estruturais e comportamento compressivo de Latossolos representativos da região dos Cerrados e potencial de uso de solos cultivados com canade-açúcar. Lavras, Universidade Federal de Lavras, 2010. 137p. (Tese de Doutorado)

SEVERIANO, E.C.; OLIVEIRA, G.C.; DIAS JÚNIOR, M.S.; OLIVEIRA, L.F.C. \& CASTRO, M.B. Pressão de preconsolidação e intervalo hídrico ótimo como indicadores de alterações estruturais do solo em decorrência das operações de colheita da cana-de-açúcar. R. Bras. Ci. Solo, 32:1419-1427, 2008.

SIGMA PLOT. Scientific Graphing Software. Versão 10.0, San Rafael, Jandel Corporation, 2006.

SILVA, V.R.; REINERT, D.J.; REICHERT, J.M. \& SOARES, J.M. Fatores controladores da compressibilidade de um Argissolo Vermelho-Amarelo distrófico arênico e de um Latossolo Vermelho distrófico típico. I - Estado inicial de compactação. R. Bras. Ci. Solo, 26:1-8, 2002.

SNEDECOR, G.W. \& COCHRAN, W.G. Statical methods. 8.ed. Ames, State University Press, 1989. 503p.

SOANE, B.D. The role of organic matter in soil compactability: A review of some practical aspects. Soil Till. Res., 16:179201,1990 .

SOIL SURVEY STAFF. Soil survey manual. Washington, USDA, 1993. 437p. (Handbook, 18)

TAYLOR, D.W. Fundamentals of soil mechanics. New York, J. Wiley, 1948. 700p.

TORMENA, C.A.; ARAÚJO, M.A.; FIDALSKI, J. \& COSTA, J.M. Variação temporal do intervalo hídrico ótimo de um Latossolo Vermelho distroférrico sob sistemas de plantio direto. R. Bras. Ci. Solo, 31:211-219, 2007.

TORMENA, C.A.; ROLOFF, G. \& SÁ, J.C. Propriedades físicas do solo sob plantio direto influenciadas por calagem, preparo inicial e tráfego. R. Bras. Ci. Solo, 22:301-309, 1998.

VEZZANI, F.M. \& MIELNICZUK, J. Uma visão sobre qualidade do solo. R. Bras. Ci. Solo, 33:743-755, 2009. 